\title{
Рудогенез Японского моря
}

Астахова Н. В.

\begin{abstract}
Аннотация
Аннотация к статье Н.В. Астаховой «Рудогенез Японского моря»

Японское море относится к тектонически активному региону планеты с развитыми процессами рифтогенной деструкции земной коры и большим количеством вулканических построек на морском дне. В многочисленных экспедициях ТОИ ДВО РАН, начиная с 70-х годах прошлого века до настоящего времени, были обнаружены многочисленные участки железомарганцевых (ЖМО), фосфоритовых и баритовых рудопроявлений. Анализ распределения этих рудопроявлений показал, что все они тяготеют к тектонически активным участкам морского дна: подводным вулканам, к тектоническим уступам или к зонам разломов. Причем, на некоторых участках совместно встречаются фосфориты и ЖМО, а на одном - фосфориты, бариты и ЖМО. В базальтах, слагающих подводные вулканические возвышенности Японского моря, обнаружено выполнение пор железомарганцевыми гидроксидами, фосфоритами или баритами.
\end{abstract}

Эти данные позволяют говорить о том, что источниками рудного вещества во всех случаях являются поствулканические газо-гидротермальные флюиды или гидротермальные растворы, циркулирующие по зонам глубинных разломов во время деструкции континентальной коры в южных и восточных частях моря. Следовательно, железомарганцевые, фосфатные и баритовые рудопроявления в Японском море связаны с низкотемпературными гидротермально-осадочными процессами.

\section{Ключевые слова:}

железомарганцевые образования, фосфориты, бариты, Японское море 


\title{
РУДОГЕНЕЗ ЯПОНСКОГО МОРЯ
}

\author{
H.В. Астахова
}

Тихоокеанский океанологический институт им. В.И. Ильичёва ДВО РАН, 690041, Россия, г. Владивосток, ул. Балтийская, д. 43

e-mail: nvast@mail.ru

\section{ВВЕДЕНИЕ}

Японское море входит в систему окраинных морей по азиатской периферии Тихого океана и располагается в зоне перехода океанической земной коры Тихого океана к континентальной коре Азиатского континента. Как и другие окраинные моря северовостока Азии, оно относится к тектонически активному региону планеты с развитыми процессами рифтогенной деструкции земной коры и большим количеством вулканических построек на морском дне. Большую часть площади моря занимают глубоководные котловины: Японская (Центральная) на западе, Ямато (Хонсю) на юго-востоке и Цусимская на юге (рис. 1). Максимальная глубина впадин - 3700, 2500 и 2000 м соответственно. Поверхность дна котловины ровная с отдельными возвышенностями (короткие хребты меридионального простирания, одиночные и сложно построенные вулканические конуса), высотой до 2 км. Длина их обычно не превышает первые десятки км. Все возвышенности сложены различными по уровню кремнезема (от базальтов до трахириолитов) вулканическими породами среднемиоцен-плейстоценового возраста, которые являются производными одной базальтовой магмы [Съедин, 1987; Емельянова, Леликов, 2010].

Юго-восточная и восточная окраины моря относятся к типу бордерленда. Докайнозойский консолидированный фундамент и палеоген-миоценовые вулканогенные толщи здесь разбиты многочисленными разломами, создавшими систему грабенов и горстов. Грабены часто заполнены осадками. Горсты образуют банки, острова и подводные валы. Вся эта сложная структура наклонена в сторону глубоководных котловин и впадин [Берсенев и др., 1987].

В центральной части моря находится самая крупная подводная возвышенность Ямато. Системой грабенов она разделена на хребет Северное Ямато, Южное Ямато и возвышенность Такуе. Длина Северного Ямато порядка 250 км, Южного Ямато- 350 км, Такуе - 225 км. Максимальная ширина 100, 75 и 70 км соответственно, а минимальная глубина 500 м. Южнее ее находятся крупные возвышенности Кита-Оки, банка Оки, хребет Оки, на юго-западе - Криштафовича, на западе - Восточно-Корейская. Последняя по 
очертаниям напоминает дугообразную форму материкового склона. Эти возвышенности имеют земную кору субматерикового типа [Берсенев и др., 1987].

В многочисленных экспедициях отдела геологии и геофизики ТОИ ДВО РАН, начиная с 70-х годах прошлого века до настоящего времени, при проведении геологического опробования на морском дне были обнаружены многочисленные участки аутигенного рудообразования: железомарганцевого, фосфатного и баритового. В данной работе будут обобщены данные по рудогенезу этого региона.

\section{МАТЕРИАЛЫ И МЕТОДЫ ИССЛЕДОВАНИЙ}

Материалом для исследования послужили рудные образцы из коллекции отдела морской геологии и геофизики ТОИ ДВО РАН. К сожалению, часть образцов железомарганцевых корок, поднятых в экспедициях 70-х - 80-х годах прошлого века была утеряна, поэтому для составления карты рудопроявлений на дне Японского моря использовались данные драгирования из отчетов морских экспедиций на нис «Первенец»

Определение породообразующих элементов в баритах и фосфоритах производилось методом «мокрой химии» в ТОИ ДВО РАН. Для определения содержания $\mathrm{Fe}, \mathrm{Mn}, \mathrm{Si}, \mathrm{Al}, \mathrm{Ca}, \mathrm{Mg}$, Ti и микроэлементов в составе ЖМК, применялся атомноэмиссионный (с индуктивно связанной плазмой) метод анализа на спектрометре Agilent 7500 с (Agilent Technologies, США) в ДВГИ ДВО РАН. Все определения элементов выполнялись в навеске анализируемого вещества, высушенной при $105^{\circ} \mathrm{C}$. Для более детального изучения были изготовлены аншлифы ЖМК, которые изучались в ДВГИ ДВО РАН на микрозондовом анализаторе JXA-8100 (JEOL Ltd., Япония) с тремя волновыми спектрометрами, доукомплектованном энергодисперсионным спектрометром INCAx sight (Oxford Instruments Analytical Ltd., Англия). Анализ осуществлялся при ускоряющем напряжении $20 \mathrm{kB}$, угол отбора излучения составлял 45. Химические анализы, полученные при анализе образцов на микрозонде, рассчитываются из интенсивностей характеристических рентгеновских линий элементов, содержащихся в образце. При сравнении интенсивностей и расчете содержаний элементов используется библиотека стандартов, данные которой обновляются не реже одного раза в квартал, а калибровка прибора проводится ежедневно. Расчет состава анализируемого образца проводится по программным комплексам, поставляемых вместе с прибором. Для проведения исследований образцы напылялись тонким слоем углерода. Объем области, в которой производилось определение химического состава, принимался, в среднем, как имеющий грушевидную форму с максимальным измерением 3-4 микрона. Количественный и полуколичественный анализ проводились по процедуре PhyRoz, включенной в стандартную программу энергодисперсионного анализатора Link ISIS.

Минеральный состав образцов определялся рентгеноспектральным и ИКспектральным анализами. 
Железомарганцевые образования (ЖМО) в Японском море были обнаружены в первых же морских экспедициях на нис «Первенец» отдела морской геологии ТОИ ДВО РАН. Впервые они были описаны И.К. Пущиным с соавторами и Л.М. Грамм-Осиповым и М.А. Репечка в 1975 году [Грамм-Осипов, Репечка, 1975; Пущин и др., 1975]. К настоящему времени в экспедициях ТОИ ДВО РАН обнаружено уже 37 районов развития железомарганцевого рудообразования (рис. 1). ЖМО Японского моря представлены, в основном, корками, мощностью от нескольких мм до 35 см, реже конгломератами (рис. 2 a, б) или жерловыми брекчиями, «пропитанными» гидроокислами Fe и $\mathrm{Mn}$, которые составляют до половины общего объема породы [Астахова, Введенская, 2003; Астахова и др., 2015, Пущин и др., 1977 и др.]. Рудные корки поднимали при драгировании привершинных частей вулканических возвышенностей, реже крутых (тектонических) уступов на склонах рифтовых долин.

Образование железомарганцевых корок Японского моря связано с гидротермальноосадочным процессом. На это указывает приуроченность их к привершинным частям подводных вулканических построек, особенности химического состава и заполнение пор подстилающих базальтов гидроксидами марганца [Скорнякова и др., 1987; Астахова, Введенская, 2003; Астахова и др., 2010, 2014; Батурин, 2012 и др.]. Основными породообразующими минералами марганца являются тодорокит и бернессит, реже пиролюзит [Скорнякова и др., 1987; Астахова и др., 2015; Батурин, 2012; Можеровский и др., 1989 и др.]. Кроме железомарганцевых, встречаются железокремнистые корки с незначительным содержанием марганца. Они образовались в результате цементации кремнеземом мелких, бесформенных обломков железистых силикатов, часто представленных селадонитом, которые содержат включения оксидов или сульфидов железа. Эти корки очень пористые. Некоторые поры и поверхность корок частично или полностью заполнены гидроокислами железа и марганца или марганца с примесью бария до 5\% [Астахова и др,. 2019]. Это указывает на осаждение марганца из растворов в последнюю стадию формирования этого типа ЖМО. При драгировании большинства подводных возвышенностей Японского моря поднимают ЖМО, относящиеся к разным группам. Это связано с тем, что при геологическом опробовании подводных возвышенностей драга протягивается по склону несколько сотен метров. В результате в драгу попадают обломки пород, находящиеся на разных участках склона. Поэтому в одной драге могут находиться ЖМО, отобранные на разном расстоянии от гидротермального источника [Астахова, 2018].

Главными элементами в ЖМО Японского моря являются марганец, железо и кремний (рис. За). Содержание их варьирует в широких пределах: Mn от 0.18 до 63.06 \%, $\mathrm{Fe}$ - от 0.01 до 42.54 \%, Si от 0.36 до 38 \%. Соответственно, значения Mn/Fe меняются от 0.01 до 9016. Причем эти значения существенно различаются не только в образцах, отобранных на разных участках развития железомарганцевой минерализации, но и поднятых на одной станции. Например, в ЖМО безымянной возвышенности (крокодил район 7) отношение $\mathrm{Mn} / \mathrm{Fe}$ изменяется от 0,87 до 9016, среднее по 12 анализам - 1761 [Астахова, Лопатников, 2016]. В таблице 1 приведены данные по среднему химическому составу 2 групп ЖМО, разделенных по соотношению Mn/Fe больше или меньше 1 . В первой группе (Mn/Fe >1) медианные значения $\mathrm{Mn}, \mathrm{Fe}$ и Si составляют 38.61, 4.00 и 5.40 
\%, во второй - 3.06, 15.20 и 24.49 \% соответственно. В ЖМО первой группы значительно выше содержание большинства микроэлементов: Ba, Sr, Co, Ni, V, Zn, Mo, Li, W (табл. 1).

Концентрация микроэлементов в ЖМО составляет десятые или сотые доли процента (табл.1). Исключение составляет барий, содержание которого может доходить до 3\%. Высокое содержание бария связано с обогащением им отдельных участков марганцевой матрицы и выделениями барита внутри рудных корок [Астахова, 2019]. Значение суммы $\mathrm{Ni}$, Co, Cu варьирует от 50 до 3323г/т, составляя в среднем 970 г/т. Максимальные значения $\mathrm{Ni}$, Со и Сu достигают $0.24 \%, 0.20$ и 0,23 \% соответственно. Распределения этих элементов неравномерно как в образцах, отобранных на разных возвышенностях, так и в пределах одной станции. Так, например, в образцах ЖМО возвышенности Первенца содержание никеля меняется от 649 до 2432 г/т, на возвышенности Витязя кобальта - от 74 до 2033 г/т, а на вулкане на северном окончании возвышенности Южном Ямато меди - от 10 до 2340 г/т [Астахова, Введенская, 2003; Астахова и др., 2015; Астахова и др., 2015]. Среди других микроэлементов относительно высокие значения у стронция, реже у молибдена, у остальных - до несколько сотен г/т (табл. 1).

При нанесении данных на классическую треугольную диаграмму Fe-Mn$(\mathrm{Ni}+\mathrm{Co}+\mathrm{Cu}) \cdot 10$, разделяющую железомарганцевые образования на гидрогенные и гидротермальные, выявляется, что они размещаются в основании диаграммы (рис. Зб), что, согласно Бонатти [Bonatti, et al.. 1972], характеризует существенно гидротермальный источник вещества, участвовавшего в железомарганцевом рудообразовании на подводных возвышенностях Японского моря. Исключение составляют лишь тонкие 2-3 мм корки на поверхности слабоуплотненной глинистой породы, отобранные у подножья вулканической постройки на севере возвышенности Южное Ямато. При этом, корки, поднятые при драгировании привершинной части этой постройки, попадают в область гидротермальных образований.

ЖМО Японского моря имеют неоднородное строение. При микрозондовом изучении аншлифов ЖМО обнаружены участки марганцевого, железо-кремнистого, марганцево-кремнистого, железо-марганцевого, марганцево-железо-кремнистого и кремнистого составов. Преобладающими являются отложения марганцевого и железокремнистого составов. Участки с разным химическим составом выделяются в форме полос с изменяющейся мощностью или в виде пятен различной формы. Границы между ними довольно четкие. Повсеместно в матрицах разного состава отмечается присутствие натрия, магния, калия, кальция, часто алюминия, бария и хлора, изредка фтора, фосфора и серы, а в единичных случаях, никеля, кобальта, свинца, молибдена, вольфрама, хрома и стронция. Во всех образцах в разных количествах обнаружены включения барита, магнетита, титаномагнетита, ильменита, пирита и других минералов, а также очень мелкие зерна самородных металлов, интерметаллических соединений, сульфидов, сульфатов, оксидов, фосфидов цветных и благородных металлов [Астахова, 2013].

Вулканические породы подводных возвышенностей Японского моря также содержат многочисленные включения металлов (Cu, Zn, Sn, Ni, Pb, As, Sb, W, Ta, Ti, Cr, Fe, $\mathrm{Ag}$ в в самородном виде, в форме интерметаллических соединений, фосфидов, силицидов (?), оксихлоридов (?), оксидов, сульфидов, сульфатов, вольфраматов. Кроме 
высокотемпературных минеральных фаз, в магматических породах обнаружены многочисленные вторичные низкотемпературные минералы: оксиды железа, марганца, кремния или их смеси, а также галит, барит и сложные алюможелезистые силикаты. Особенности состава, локализации (микротрещины, микропустоты и т.д.), морфология и размеры выделений минеральных фаз свидетельствуют о формировании в результате наложенного поствулканического гидротермального процесса. Подтверждением наложенного характера процесса является совместное нахождение в одних и тех же полостях высоко-, средне- и низкотемпературных минеральных фаз. Причем, последние первичны по отношению к металлическим минеральным фазам [Астахова и др., 2014].

Вулканизм на подводных возвышенностях Японского моря имел длительный и пульсирующий характер. Он периодически возобновлялся в течение продолжительного времени, начиная со среднего миоцена. Все это обусловило масштабность и долговременность поствулканических гидротермальных процессов. По ослабленным трещиноватым зонам растворы пронизывали все слагающие возвышенности породы, но максимально их действие проявилось в наиболее проницаемой (прижерловой) части морфоструктур. В результате в привершинных частях вулканических построек произошло образование железомарганцевых корок, содержащих включения зерен акцессорных металлов. Учитывая, что подстилающие вулканические породы, как и ЖМО, наиболее обогащены никелем и кобальтом, можно сделать вывод, что они являются основным источником цветных металлов. В тоже время, часть акцессорных металлов попадают в гидротермальный раствор при выщелачивании сульфидов, отложившихся на более низких горизонтах, а высокотемпературные соединения, фосфиды и интерметаллы могли переноситься в твердой фазе с восходящими потоками магматических высокотемпературных рудоносных флюидов [Астахова, 2018].

\section{ФОСФОРИТЫ}

Под фосфоритом понимается фосфоросодержащая горная порода, количество $\mathrm{P}_{2} \mathrm{O}_{5}$ в которой не менее 5 \%. Впервые фосфориты в Японском море были обнаружены М.И. Липкиной в 1979 году при ревизии каменного материала, поднятого при драгировании подводного вулкана Ченцова на восточном краю Восточно-Корейской подводной возвышенности [Липкина, Школьник, 1981]. Позже были подняты фосфориты при драгировании возвышенностей Северное и Южное Ямато, Шевалдина, Криштофовича, Уллындо, Хокусан-Се, безымянной, хребта Оки и с материкового склона Приморья (рис. 1) [Берсенев и др., 1982; Липкина, Цой, 1999; Гусев В.В, 1986 и др] в многочисленных экспедициях ТОИ ДВО РАН в 70-80 х годах прошлого века.

По материалам драгирования выделяются три основные типы фосфоритов Японского моря: фосфотизированные диатомиты, фосфатные желваки и псаммитопсефитовые породы с фосфотизированным цементом [Берсенев и др., 1983; Гусев, 1986; Леликов, 2001].

Фосфотизированные диатомиты имеют самое широкое распространение. Они обнаружены на всех крупных подводных возвышенностях и ряде вулканических построек. 
Среди них выделяются массивные и слабоконсолидированные разности. Массивные фосфориты подняты в виде обломков остроугольной формы с раковистым изломом (рис. 2в), иногда плитчатой формы. Размер обломков от 2-3 до 32 см. Это твердые, с высоким удельным весом (2.84-2.86 г/см³), массивные, иногда тонкослоистые или брекчевидные породы от светло-коричневого до темно-коричневого цвета, с небольшими пустотами, выполненными рыхлым фосфатным материалом. На крупных обломках на одной из сторон обычно имеется очень характерная черная, блестящая, «почковидная» поверхность. На возвышенности Северное Ямато была поднята глыба базальта с коркой фосфорита, имеющего такую же поверхность. При высыхании породы, корка отделилась от базальта.

Образцы фосфорита на 75-80 \% сложены светло-желтым изотропным фосфатом, содержащим неравномерную примесь тонкоалевритовых терригенных частиц и аутигенные минералы: кристаллы барита, глауконит, пирит-мельниковит, гидроксиды железа и марганца.. Результаты микроскопического, рентгеноструктурного, ИКспектрального, термогравиметрического анализов с учетом химического состава позволяют отнести эти фосфориты к фторкарбонатаппатиту (франколиту) [Берсенев и др., 1983].

Слабоконсолидированные фосфориты установлены только на Восточно-Корейской

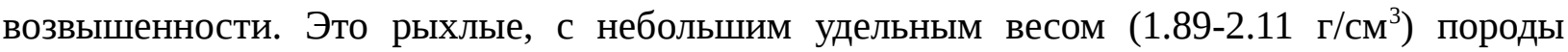
светло бежевого цвета. Часто в образцах наблюдаются постепенные переходы от твердых фосфоритов центральной части образца к слабоконсолидированным разностям краевых частей глыб. Содержанием $\mathrm{P}_{2} \mathrm{O}_{5}$ в обеих типах фосфотизированных диатомитов практически одинаково от 20 до 30\%.

Фосфатные желваки уплощенные, «лепешковидные», в плане округлые и иногда неправильные. Размер от 1*5 до 2-5*20 см. Поверхность неровная, шероховатая без признаков окатанности. Цвет серый, темно-серый, в изломе да черного. Тонкая параллельная слоистость огибает центр - ядро. Последнее округлой формы состоит из коричневого фосфата, иногда замещающего скопления диатомей, и постоянно содержат обломки костей, фосфатизированные фораминиферы, раковины. Периферическая зона сложена фосфатизированными раковинами диатомовых. Содержание $\mathrm{P}_{2} \mathrm{O}_{5}-27$-30 \%. Они встречаются преимущественно на возвышенностях Северное и Южное Ямато и, изредка, на Восточно-Корейской.

В кремнисто-карбонатных конкрециях с материкового склона Приморья, диаметром от 5 до 40 см, в ядрах которых встречаются кости позвоночных животных, а периферические зоны сложены терригенно-карбонатным фосфотизированным материалом содержание фосфора значительно меньше (10-12 \% $\left.\mathrm{P}_{2} \mathrm{O}_{5}\right)$.

Псаммито-псефитовые породы с фосфатизированным цементом характеризуются низким содержанием $\mathrm{P}_{2} \mathrm{O}_{5}$ (3-10 \%). Они представляют собой обломки от неравномернообломочных грубых песчаников до мелкогалечниковых конгломератов, размером до 5*10 см. Терригенный материал, составляющий более 50\% объема, представлен хорошо окатанными гальками гранитоидов, кислых и средних эффузивов, редко фосфоритами, а также зернами кварца, полевых шпатов, глауконита и погружен в базальный цемент из 
массы фосфатизированных диатомей. Встречаются на возвышенностях Ямато и, изредка, Восточно-Корейской и хребте Оки.

Все находки фосфоритов приурочены к базальным горизонтам морских неогеновых отложений. Последние несогласно перекрывают породы докайнозойского консолидированного фундамента и палеоген-раннемиоценовые базальтоиды. Имеющиеся определения возраста фосфоритов свидетельствуют, что они формировались в позднемиоценовых осадках, отлагающихся в ранний (Восточно-Корейская возвышенность), средний (возвышенность Уллындо, хребет и банка Оки) и поздний (возвышенность Северное Ямато) периоды этой эпохи. Фосфориты найдены преимущественно на склонах подводных возвышенностей в интервале глубин 1150-2150 м. Исключение составляют незначительное количество фосфоритов с низким содержанием $\mathrm{P}_{2} \mathrm{O}_{5}$, поднятых при драгировании материкового склона Приморья в интервале 450-600 м и на хребте Оки (глубина 330м) [Берсенев и др., 1983; Леликов, 2001].

Средний химический состав фосфоритов приведен в табл. 2. Во всех пробах, где определялся фтор, отмечается его высокое содержание (1.29 - 3.3\%).

В 80-х годах прошлого века в нескольких экспедициях ТОИ ДВО РАН проводилось целенаправленное изучение фосфоритов Японского моря. Наиболее детально был изучен участок на Восточно-Корейской возвышенности, где было сделано более 150 станций драгирования, отобраны колонки донных осадков и выполнено непрерывное сейсмопрофилирование. Участок имеет округлую форму диаметром 3.5 км и находится в интервале глубин 1300-2200 м на крутом северо-восточном склоне вулкана Ченцова на восточном борту центральной части возвышенности. Фосфориты на этом участке представлены, в основном, твердыми фосфотизированными диатомитами, реже слабоконсолидированными. Отмечаются единичные находки желваков и конкреций [Леликов, 2001].

Вопрос о происхождении фосфоритов Японского моря окончательно не решен. Существуют две прямо противоположные точки зрения на их образование.

По мнению В. Гусева [Гусев, 1986], придерживающего биохимической теории их образования, источником фосфора могли быть холодные воды течения палео-Ойясио, поступающие в период похолодания в среднем миоцене из Тихого океана. В поверхностном слое в холодных водах в зоне современного этого течения наблюдаются максимальные для Тихого океана содержания растворенного органического фосфора [Батурин, 1978]. На крупных возвышенностях в этот период преобладали шельфовые условия с высокой биопродуктивностью, благоприятные для формирования органогенных осадков с высоким содержанием фосфора в иловых водах.

Другие исследователи связывают фосфатообразование в Японском море с кайнозойским вулканизмом [Липкина, Школьник, 1981; Липкина, 1998; Гнидаш и др., 1988; Гнидаш, Съедин, 1991]. На это указывают приуроченность районов развития фосфоритообразования к подводным вулканическим возвышенностям и высокое содержание $\mathrm{P}_{2} \mathrm{O}_{5}(0.1-1.7 \%)$ в базальтах Японского моря. О гидротермальном 
поступлении фосфора свидетельствуют выполнение пор в туфах базальтов вторичными минералами, где наряду с калиевыми железистыми слоистыми силикатами находятся кристаллы фторкарбонатаппатита. Авторы считают, что накопление фосфора, вероятно, происходило в результате постмагматических процессов, Он отлагался не только в виде вторичных минералов в измененных участках пород, но и поступал в морскую воду в составе гидротерм и мог мигрировать и отлагаться вдали от источника.

Наиболее вероятно предположение о гидротермальном поступлении фосфора. В частности, самый большой участок рудопроявления фосфоритов на Восточно-Корейской возвышенности сложен вулканическими породами, миоценовыми и голоценовыми отложениями. Распространенный в этом районе комплекс пород сформировался в сильно эродированном кратере или кальдере вулкана. Здесь локально распространена ограниченная ассоциация геологических образований: базальты, базальтовые туфы, пемзовые туфы, слабосцементированные осадочные отложения, гравийно-галечный материал четвертичного ледового разноса, фосфориты, кварцево-глауконитовые породы (железокремнистые корки), железомарганцевые корки [Съедин, 1987]. Вулканические породы фосфатизированы и глаукотизированы. Содержание $\mathrm{P}_{2} \mathrm{O}_{5}$ в них варьирует от 0.46 до 10.78 \%. Франколит встречен в кавернах, порах и трещинах базальтов и в цементе туфов в парагенезисе с глауконитом и пиритом. В некоторых образцах базальтов в порах встречаются микродрузы белых кристаллов барита [Липкина, 1998].

О гидротермальной деятельности на вулкане Ченцова также свидетельствует колонка донных осадков длиной 238 см, поднятая трубкой в его кальдере на глубине 1800 м. Она представлена миоценовыми отложениями, перекрытыми 7 мм слоем эдафогенных осадков, предположительно голоценового возраста. Разрез миоцена на всю мощность пронизан многочисленными современными студнеобразными интенсивно пиритизированными зелеными глинами самой разнообразной формы. Они отчетливо выделяются по разрезу трубки и внешне напоминают жильные тела. Это извивающиеся тонкие жилки или устремленные вверх пунктирные, линзовидные тела. Пирит здесь представлен как хорошо ограненными кубическими кристаллами, так и фрамбоидами. Также встречается барит и франколит. Фосфатная минерализация является наложенной. Франколитом избирательно замещена наиболее проницаемая часть разреза, обогащенная створками диатомей и глауконитом [Липкина, Пушкарь, 2001].

Образование кремнисто-карбонатных конкреций с материкового склона Приморья связано с диагенетическими процессами [Астахова и др., 1993]. Конкреции с небольшим (10-12 \% $\mathrm{P}_{2} \mathrm{O}_{5}$ ) содержанием фосфора встречаются только в районе залива Петра Великого. Так как в этот залив впадают многочисленные реки Южного Приморья, то, вероятнее всего, повышение содержания фосфора в осадке связано с выносом этих рек.

\section{БАРИТ}

В Японском море единичные кристаллы аутигенного барита встречаются довольно часто. Находки его приурочены в основном к отложениям миоценового возраста, поднятым со склонов подводных вулканов. Крупные скопления бария в виде баритовых 
конкреций обнаружены в миоценовых отложениях восточной и центральной частях моря: на банках бордерленда о. Хонсю, на юго-востоке возвышенности Северное Ямато, на западном склоне хребта Окусири у берегов Хоккайдо. В указанных районах находки баритовых конкреций приурочены к тектоническим нарушениям, ограничивающим эти структуры. В основном конкреции имеют шаровидную, эллипсовидную или уплощенную, лепешковидную форму. Реже встречаются субцилиндрические или неправильные формы. Но по внутреннему строению конкреции из различных районов Японского моря значительно различаются между собой. Наиболее простое строение имеют конкреции с бордерленда о-ва Хонсю, самое необычное - конкреции, поднятые при драгировании склона хребта Окусири (рис. 2 г-е).

Банки бордерленда о. Хонсю представляют собой платообразные возвышенности с минимальной глубиной от 200 до 400 м, разделенные трогами, глубиной 800-1000 м. Впервые баритовые конкреции были обнаружены японскими геологами в конце 60-х годов на банках Сингури, Торимигури, Окикамагури и в заливах Акита и Садо [Okada et al., 1971; Sakai, 1971]. В 1980 г. в экспедиции ТОИ ДВО РАН при драгировании склонов и вершинных еще 5 банок севернее острова Садо также были подняты баритовые конкреции [Астахова, Мельниченко, 2002]. Поднятые конкреции зеленовато - серого цвета, имеют округлую, овальную, цилиндрическую или неправильную форму, с максимальным размером 20*10*8 см (рис. 2г), с округлым или овальным сечением. Поверхность конкреций ровная, серого цвета. Внутреннее строение одних конкреций однородное, у других выделяются центральная темно-серая часть и ряд концентрических слоев светло- и темно-серого цвета. Внутри некоторых конкреций отмечаются трещины синерезиса, выполненные кальцитом. В шлифах видно, что конкреции образованы мелкозернистым баритом (0,02-0,1 мм) с примесью радиолярий, диатомей и терригенных минералов. Содержание BaSO4 в конкрециях варьирует от 62,69 до 84,84 \%. Они встречаются в толще диатомовых аргиллитов, возраст которых - конец среднего - начало позднего миоцена (10-8 млн лет) [Okada et al., 1971].

На возвышенности Северное Ямато при драгировании крутого уступа в юговосточной части в интервале 1200-1300 м было поднято около 50 кг целых баритовых конкреций и их фрагментов . Баритовые конкреции имеют различную величину и форму: сферическую, диаметром 3-7 см; лепешковидную, диаметром 4-7 см и толщиной 1,5-2 см; гантелеобразную, длиной от 3 до 32 см с диаметром 1,5-7 см. (рис. 2е) [Липкина, Цой, 1980; Астахова, Мельниченко, 2002]. Поверхность конкреций неровная, бугорчатая, в большинстве случаев с одной стороны покрыта гидроокислами марганца. На некоторых конкрециях сохранился слой вмещающего осадка - диатомита. Комплекс диатомей характеризует верхний миоцен Северо-Тихоокеанской области [Липкина, Цой, 1980]. Внутреннее строение конкреций неравномерно-кристаллическое. У большинства конкреций примерно треть объема занимает внутреннее ядро, резко обособленное от внешней периферийной части. Ядро сложено лучистым крупнокристаллическим баритом зеленовато-белого или светло-розового цвета. Величина кристаллов барита в лучистых сростках достигает 1,2 см. Периферические части конкреций также сложены радиальнолучистым баритом, но кристаллы значительно меньше по размеру и различимы только под микроскопом. В этой зоне наблюдается примесь радиолярий и диатомей. Содержание 
$\mathrm{BaSO}_{4}$ в центральной и периферийной частях конкреции составляет 98 \% и 74 \% соответственно, в валовой пробе - 89.51\%.

Баритовые конкреции хребта Окусири были подняты при драгировании его западного склона на глубине 1560 - 1400 м [Астахова и др., 1990]. Они имеют шаровидную и эллипсоидальную форму. Поверхность их серого цвета, слегка шероховатая. На срезе шарообразной конкреции диаметром 4 см отчетливо выявляется зональное строение: темно-серое ядро и более светлая оторочка толщиной 0,5 см. Конкреция образована мелкозернистым баритом, в шлифе отмечаются большое количество диатомей разной сохранности и очень мелкие глобули диагенетического пирита. Пирит развивается как по основной массе, так и по органическим остаткам.

Конкреции овальной формы с максимальным размером 6*2,5*2 см имеют необычное строение. Внешнюю часть их составляет слой серого мелкокристаллического барита шириной 2-3 мм, в раздувах до 6 мм. В центральной части конкреций прослеживается прослой барита черного цвета (плоскость, секущая конкрецию по длине) (рис. 2 д). В одних случаях он оканчивается во внешнем сером слое, в других - выходит за пределы конкреции. Толщина этого слоя колеблется от 1 до 5 мм. На старых сколах он охристый за счет гидроокислов железа. Пространство между оболочкой и черным прослоем заполнено диатомовым илом. По данным биостратиграфического анализа, комплекс диатомей этого ила аналогичен комплексу верхнемиоценовой зоны Rouxia californica (7,4-6,0 млн. лет) [Астахова и др., 1990]. Можно предположить, что первоначально было образовано пластовое тело черного барита. Затем, вероятно, в результате тектонических процессов оно было раздроблено на фрагменты, вокруг которых в осадке начался рост баритовых конкреций.

Рудная минерализация в баритовых конкрециях представлена сульфидом железа и распространена крайне неравномерно. В прожилке черного барита отмечаются единичные очень мелкие гнезда октаэдрических кристаллов сульфида. Основная часть рудного материала наблюдается в сером барите и приурочена к припрожилковым участкам. В количественном отношении значительно преобладают глобулы размером 2-3 мкм. Отмечаются единичные скопления, в каждом из которых присутствует по 6-10 глобулей. Помимо этого пирит неравномерно замещает органические остатки, образуя при этом сетчатые, сотовидные текстуры.

Химический состав баритовых конкреций приведен в таблице 3. Кроме относительно высокого содержания железа, черный барит обогащен $\mathrm{As}, \mathrm{Cu}, \mathrm{Co}, \mathrm{Zn}, \mathrm{Pb}$ и Мо по сравнению с серым.

Образование маломощных пластовых тел барита в среднем миоцене вполне допустимо в этом районе. Подводный хребет Окусири начинается резко выраженным поднятием вблизи о-ва Окусири и протягивается отсюда к юго-западной части Хоккайдо [Геологическое развитие..., 1968], где ведется разработка стратиформного баритполиметаллического месторождения (рудник Тойя 2) [Геохимия ..., 1982]. Это месторождение типа Куроко приурочено к морским миоценовым отложениям [Мейнард, 1985].

Известно, что почти все барит-полиметаллические залежи руд Куроко 
располагаются на одном и том же стратиграфическом уровне и формировались в течение очень небольшого промежутка времени в конце стадии Нисикуросава в среднем миоцене. На это время приходятся спад вулканической активности и максимальное прогибание коры. Именно в данный период в небольших впадинах рельефа дна, где циркуляция морских вод была ограниченной и не происходило размыва содержащих сульфиды осадков, сформировалось несколько самостоятельных месторождений [Мейнард, 1985]. Но, вероятно, часть гидротермальных растворов не выходила на поверхность дна, а растекалась в толще осадка, где смешивалась с иловыми водами. В результате реакции барийсодержащих растворов и сульфата иловых вод произошло постепенное образование баритовых конкреций.

Учитывая, что все находки баритовых конкреций в Японском море тяготеют к зонам глубинных разломов пояса Садо-Окусири и возвышенности Ямато, где в среднем миоцене отмечалась гидротермальная активность [Геологическое развитие..., 1968], можно принять источником бария гидротермальные растворы, поднимающиеся по этим разломам, но не выходящие на поверхность морского дна. Такой процесс наблюдается в настоящее время во впадине Дерюгина (Охотского моря), где в осадке происходит образование тонких прожилков, мелких гнезд и микроконкреций барита [Астахова, Сорочинская, 2001]. В изученном районе хребта Окусири железо-бариевые и бариевые гидротермальные растворы поступали с перерывом по времени. При этом пластовые тела черного барита, как более ранние, впоследствии были раздроблены более поздними тектоническими подвижками.

\section{ЗАКЛЮЧЕНИЕ}

Анализ распределения железомарганцевых, фосфоритовых и баритовых рудопроявлений в Японском море показал, что все они тяготеют к тектонически активным участкам морского дна: подводным вулканам, к тектоническим уступам или к зонам разломов. Причем, на некоторых вулканах, в частности, на возвышенности Шевалдина, в разное время были подняты фосфориты и маломощные марганцевые и железокремнистые корки, а на юго-западной части возвышенности Северное Ямато - фосфориты, бариты и железомарганцевые корки.

В составе ЖМО Японского моря присутствует барий и фосфор. Они могут обогащать отдельные участки рудной матрицы и/или находиться в виде включений зерен барита или фосфидов. Кроме этого, фосфор может входить в состав комплексных соединений сульфидов цветных металлов [Астахова, 2013, 2018, 2019]. В фосфоритах выявлены включения аутигенных кристаллов барита и содержание МпО до 0.87 \% [Липкина, 1981; Леликов, 2001]. В базальтах, слагающих подводные вулканические возвышенности Японского моря, обнаружено выполнение пор железомарганцевыми гидроксидами, фосфоритами или баритами [Астахова и др., 2014; Липкина, 1998].

Эти данные позволяют говорить о том, что источниками рудного вещества во всех случаях являются поствулканические газо-гидротермальные флюиды или гидротермальные растворы, циркулирующие по зонам глубинных разломов во время 
деструкции континентальной коры в южных и восточных частях моря. Следовательно, железомарганцевые, фосфатные и баритовые рудопроявления в Японском море связаны с низкотемпературными гидротермально-осадочными процессами.

Работа выполнена по госбюджетной теме «Палеоокеанология окраинных морей Востока России и примыкающих районов Тихого океана, особенности и этапность кайнозойского осадконакопления, магматизма и рудогенеза» (№ AAАA-А17117030110033-0).

\section{ЛИТЕРАТУРА}

1. Астахова Н. В. Баритовая минерализация в осадках окраинных морей западной части Тихого океана // Тихоокеанская геология, 1996, т.15, № 5, с. 103-109.

2. Астахова Н. В., Введенская И.А. Химический состав и генезис железомарганцевых образований подводных вулканов и возвышенностей Японского моря // Вулканология и сейсмология, 2003, № 6, с. 1-8.

3. Астахова Н.В. Барий в железомарганцевых образованиях Японского моря: особенности выделения и взаимоотношение с основными рудными фазами // Вестник ИГ Коми НЦ УрО РАН, 2019, № 3, с. 31-40. DOI: 10.19110/2221-1381-201903-31-40.

4. Астахова Н.В. Железомарганцевые корки центральной котловины Японского моря //Литология и полезные ископаемые, 2018, № 5, с. 384-396.

5. Астахова Н.В. Колесник О.Н., Съедин В.Т. Рудная минерализация в вулканических породах подводных возвышенностей Японского моря // Геохимия, 2014, № 2, с. 158-177.

6. Астахова Н.В. Колесник О.Н., Съедин В.Т. Цветные, благородные и редкоземельные металлы в железо-марганцевых корках и базальтах возвышенности Беляевского (Японское море) // Вестник КРАУНЦ. Серия НАУКИ О ЗЕМЛЕ, 2010, № 2, вып. 16, с. 152-166. http://www.kscnet.ru/kraesc/2010/2010_16/2010_16.html

7. Астахова Н.В. Формы нахождения и особенности распределения благородных и цветных металлов в железомарганцевых корках Японского моря //Океанология, 2013, т. 53, (6), с. 769-785.

8. Астахова Н.В., Ващенкова Н.Г., Горбаренко С.А. Карбонатные образования из неогеновых отложений материкового склона Приморья // Тихоокеанская геология, 1993, № 1, с. 32-38

9. Астахова Н.В., Лопатников Е.А, Цой И.Б. Геохимия марганцевых конгломератов возвышенности Витязя (Японское море) // Вулканология и сейсмология, 2015, № 6, c. $13-23$.

10. Астахова Н.В., Лопатников Е.А. Состав и парагенетические ассоциации массивного пиролюзита из глубоководной котловины Японского моря // Геология и геофизика, 2016, т. 57, (10), с. 1861-1874.

11. Астахова Н.В., Лопатников Е.А., Можеровский Ф.В., Ярощук Е.И. Гидротермальные отложения возвышенности Первенца (Японское море) // Вулканология и сейсмология, 2019, № 4, с. 29-39. DOI: https://doi.org/10.31857/S0203-03062019429-39 
12. Астахова Н.В., Мельниченко Ю.И. Баритовые конкреции Японского моря // Литология и полезные ископаемые, 2002, № 1, с. 44-52.

13. Астахова Н.В., Ожогина Е.Г., Цой И.Б. Баритовые конкреции северной части Японского моря// Тихоокеанская геология, 1990, №4, с. 16-21.

14. Астахова Н.В., Сорочинская А. В. Баритовая и карбонатная минерализация в осадках впадины Дерюгина Охотского моря // Океанология, 2001, т. 41 (3), с. 447455.

15. Астахова Н.В., Съедин В.Т., Можеровский А.В., Лопатников Е.А. Первая находка массивного пиролюзита в глубоководной котловине Японского моря // ДАН, 2015, т. 462, №1, с. 68-72.

16. Батурин Г.Н. Геохимия гидротермальных железомарганцевых корок Японского моря // ДАН, 2012, т. 445, № 2, с. 179-184.

17. Берсенев И.И., Леликов Е.П., Безверхний В.Л., Ващенкова Н.Г., Съедин В.Г., Tepexоа Е.П., Цой И.Б. Геология дна Японского моря. Владивосток: ДВНЦ АН СССР, 1987, 140 с.

18. Берсенев И.И., Школьник Э.Л., Гусев В.В. Фосфориты дна Японского моря // Докл. АН СССР, 1983. Т. 271, № 2, с.397-409.

19. Геологическое развитие Японских островов. Под ред. М. Масао, Г. Масао, Ф. Мицуо. М.: Мир, 1968, 720 с.

20. Геохимия гидротермальных рудных месторождений. Под ред. Х.П. Барнса. М.: «Мир», 1982, 624 с.

21. Гнидаш М.И., Съедин В.Т. О связи фосфатонакопления с подводным вулканизмом // Сов. Геология, 1991, № 10, с. 39-43.

22. Гнидаш М.И., Съедин В.Т., Можеровский А.В., Якушева И.Н. Геохимические ассоциации фосфора в базальтах Японского моря // Тихоокеанская геология, 1988, № 3, с. 25-34.

23. Грамм-Осипов Л.М. Репечка М.А. Марганцевые корки на дне Японского моря // Океанология, 1975, т. 15, вып. 4, с. 672-674.

24. Гусев В.В. Фосфориты Японского моря. Состав и генезис: Автореф. дис. к.г.-м.н. Новосибирск, 1986, 17 с.

25. Емельянова Т.А., Леликов Е.П. Миоцен-плейстоценовый вулканизм глубоководных котловин Японского и Охотского морей // Тихоокеанская геология, 2010, т. 29, № 2, с. 57-68.

26. Леликов Е.П. Геология фосфоритов дна Японского моря. Владивосток: Дальнаука, 2001, 117 с.

27. Липкина М. И., Пушкарь В.С. Стратифицированные гидротермальные фосфорит-глауконитовые отложения миоцена на ст. 2617-А с подводного вулкана Ченцова в Японском море // Геология морей и океанов. Тез. докл. XIV Международной школы морской геологии, т. 1. М.: ГЕОС, 2001, с 328-329.

28. Липкина М.И. Фосфатная и сопутствующая минерализация в магматических породах подводного вулкана Ченцова (Японское море) // Тихоокеанская геология, 1998, т. 17, № 3, с. 81-93.

29. Липкина М.И., Цой И.Б. Конкреции барита с подводной возвышенности Ямато в Японском море// Докл. АН СССР, 1980, т. 254, № 4, с.1002-1005. 
30. Липкина М.И., Цой И.Б. О возрасте и генезисе фосфатной минерализации на Северном Ямато в Японском море // Тихоокеанская геология, 1999, т. 17, № 3, с. 8193.

31. Липкина М.И., Школьник Э.Л. Фосфориты с подводного вулкана Ченцова в Японском море // Докл. АН СССР, 1981, т. 257, № 1, с. 217-222.

32. Мейнард А.В. Геохимия осадочных рудных месторождений. М.: Мир, 1985, 358 с.

33. Михайлик П.Е., Михайлик Е.В., Зарубина Н.В., Баринов Н.Н., Съедин В.Т., Леликов Е.П. Вещественный состав и распределение РЗЭ в железомарганцевых корках подводных возвышенностей Беляевского и Медведева (Японское море) // Тихоокеанская геология, 2014, т. 33, № 5, с. 3-16.

34. Можеровский А.В., Грамм-Осипов Л.М., Волкова Т.И., Можеровская Л.В. Минералогические особенности железо-марганцевых образований Японского моря. В кн.: Новые данные по геологии западной части Тихого океана. Владивосток: ДВО АН СССР, 1989, с. 135-139.

35. Пущин И.К., Берсенев И.И., Берсенев Ю.И., Леликов Е.П., Терехов Е.П. О находке железо-марганцевых конкреций в северо-западной части Японского моря. В кн.: Геология окраинных морей Тихого океана. Владивосток, ДВНЦ, 1975, с. 9495.

36. Скорнякова Н.С., Батурин Г.Н., Гурвич Е.Г., Успенская Т.Ю., Краснов С.Г., Гнидаш М.И. Железомарганцевые корки и конкреции Японского моря // Докл. АН СССР, 1987, т. 293, № 2, с. 430-434.

37. Съедин В.Т. Особенности геологического строения фосфоритоносного участка Ченцова (Японское море) // Геология Тихого океана. Тез. докл. На 111 Тихоокеанской школе по морской геологии, геофизике и геохимии. Владивосток: ДВО АН СССР, 1987, с. 85-89.

38. Съедин В.Т. Формационно-геохимические типы кайнозойских базальтоидов Японского моря // ДАН СССР, 1987, т. 296, № 6, с. 1441-1446.

39. Bonatti, E., Honnorez, J., Joensuu, O., Rydell, H. Classification and genesis of submarine iron manganese deposits, in: Horn, D.R. (Ed.),Ferromanganese Deposits on the Ocean Floor. National Science Foundation, Washington, D.C., 1972, pp. 149-166.

40. Okada K., Kato S., Kobayashi S.I. The barite nodules from the Sin-Guri Bank, Japan Sea // J. Mining and Mat. Inst. Jap., 1971, V. 87, № 1002, p. 594-598.

41. Sakai H. Sulfur and oxygen isotopic study of barite concretions from banks in the Japan Sea of the Northeast Honshu, Japan // Geochem. J., 1971, V. 5, № 2, p. 79-83. 
Подписи к рисункам к статье Н.В. Астаховой «Рудогенез Японского моря»

Рис. 1. Карта рудопроявлений Японского моря.

1 - железомарганцевые образования; 2 - фосфориты; 3 - бариты.

Рис. 2. Руды Японского моря

а-б - ЖМО: железомарганцевая корка возвышенности Беляевского (а) и конгломерат с марганцевым цементом с возвышенности Витязя; в - фосфорит Восточно-Корейской возвышенности; г-е - баритовые конкреции: банки Косидзи, бордерленд о-ва Хонсю (г), хребта Окусири (д) и возвышенности Северное Ямато (е).

Рис. 3. Состав ЖМО Японского моря на диаграммах Fe-Mn-Si (a) и $\mathrm{Fe}-\mathrm{Mn}-(\mathrm{Ni}+\mathrm{Co}+\mathrm{Cu}) * 10$ (Е. Бонатти) (б). 
Таблица 1. Средний химический состав ЖМО Японского моря (Fe-P в \%, Ba-U - г/т)

\begin{tabular}{|c|c|c|c|c|c|c|c|c|c|c|c|}
\hline \multirow[b]{2}{*}{ элементы } & \multicolumn{5}{|c|}{$\mathrm{Mn} / \mathrm{Fe}^{>} 1$} & \multirow[b]{2}{*}{ элементы } & \multirow[b]{2}{*}{$\begin{array}{c}\text { К-во } \\
\text { про } \\
\text { б }\end{array}$} & \multicolumn{4}{|c|}{$\mathrm{Mn} / \mathrm{Fe}^{<} 1$} \\
\hline & $\begin{array}{l}\text { к-во } \\
\text { проб }\end{array}$ & медиана & минимум & максимум & $\begin{array}{l}\text { станд. } \\
\text { откл. }\end{array}$ & & & медиана & $\begin{array}{c}\text { миниму } \\
\text { м }\end{array}$ & максимум & $\begin{array}{c}\text { станд. } \\
\text { откл. }\end{array}$ \\
\hline $\mathrm{Fe}$ & 66 & 4.00 & 0.01 & 15.45 & 4.26 & $\mathrm{Fe}$ & 14 & 15.20 & 5.38 & 42.54 & 10.51 \\
\hline $\mathrm{Mn}$ & 66 & 38.61 & 12.60 & 63.06 & 15.19 & $\mathrm{Mn}$ & 14 & 3.06 & 0.18 & 16.84 & 4.50 \\
\hline $\mathrm{Si}$ & 51 & 5.40 & 0.36 & 20.83 & 5.29 & $\mathrm{Si}$ & 13 & 24.49 & 7.81 & 38.00 & 9.07 \\
\hline $\mathrm{Al}$ & 58 & 0.97 & 0.03 & 4.10 & 0.91 & $\mathrm{Al}$ & 13 & 1.89 & 0.01 & 8.82 & 3.19 \\
\hline $\mathrm{Ti}$ & 56 & 0.07 & 0.003 & 0.89 & 0.16 & $\mathrm{Ti}$ & 14 & 0.16 & 0.001 & 0.95 & 0.33 \\
\hline$P$ & 28 & 0.09 & 0.01 & 0.25 & 0.06 & $\mathrm{P}$ & 7 & 0.10 & 0.01 & 0.26 & 0.10 \\
\hline $\mathrm{Ba}$ & 49 & 7114 & 110 & 29667 & 6512 & $\mathrm{Ba}$ & 13 & 601 & 38 & 2328 & 754 \\
\hline Co & 66 & 300 & 10 & 2033 & 345 & Co & 14 & 50 & 3 & 143 & 50 \\
\hline $\mathrm{Cr}$ & 58 & 25 & 0.4 & 130 & 25 & $\mathrm{Cr}$ & 13 & 55 & 2 & 213 & 81 \\
\hline $\mathrm{Cu}$ & 66 & 201 & 7 & 1500 & 250 & $\mathrm{Cu}$ & 14 & 208 & 3 & 2340 & 615 \\
\hline $\mathrm{Ni}$ & 66 & 589 & 41 & 2432 & 486 & $\mathrm{Ni}$ & 14 & 128 & 27 & 437 & 104 \\
\hline $\mathrm{Pb}$ & 49 & 32 & 1 & 508 & 78 & $\mathrm{~Pb}$ & 13 & 54 & 2 & 395 & 110 \\
\hline $\mathrm{Sr}$ & 49 & 1294 & 480 & 2898 & 552 & $\mathrm{Sr}$ & 13 & 167 & 7 & 589 & 152 \\
\hline $\mathrm{V}$ & 42 & 345 & 44 & 1624 & 300 & $\mathrm{~V}$ & 12 & 107 & 6 & 388 & 110 \\
\hline $\mathrm{Zn}$ & 59 & 232 & 24 & 610 & 151 & $\mathrm{Zn}$ & 14 & 104 & 7 & 286 & 90 \\
\hline $\mathrm{Zr}$ & 41 & 37 & 1 & 312 & 58 & $\mathrm{Zr}$ & 12 & 42 & 1 & 122 & 46 \\
\hline Mo & 54 & 309 & 86 & 1730 & 277 & Mo & 10 & 56 & 3 & 209 & 72 \\
\hline $\mathrm{Li}$ & 53 & 238 & 4 & 902 & 287 & $\mathrm{Li}$ & 9 & 29 & 9 & 55 & 17 \\
\hline As & 36 & 45 & 17 & 78 & 16 & As & 8 & 78 & 4 & 251 & 87 \\
\hline $\mathrm{Rb}$ & 36 & 20 & 0.4 & 91 & 21 & $\mathrm{Rb}$ & 8 & 76 & 18 & 156 & 56 \\
\hline $\mathrm{W}$ & 36 & 96 & 3 & 427 & 93 & $\mathrm{~W}$ & 8 & 16 & 2 & 89 & 30 \\
\hline $\mathrm{U}$ & 35 & 9 & 0.3 & 21 & 6 & $\mathrm{U}$ & 8 & 4 & 0.5 & 15 & 5 \\
\hline$(\mathrm{Ni}+\mathrm{Co}+\mathrm{Cu}) * 10$ & 66 & 1.09 & 0.07 & 3.32 & 0.77 & $(\mathrm{Ni}+\mathrm{Co}+\mathrm{Cu}) * 10$ & 14 & 0.39 & 0.05 & 2.43 & 0.61 \\
\hline $\mathrm{Mn} / \mathrm{Fe}$ & 66 & 405 & 1.1 & 9016 & 1534 & $\mathrm{Mn} / \mathrm{Fe}$ & 14 & 0.28 & 0.01 & 0.90 & 0.32 \\
\hline$(\mathrm{Fe}+\mathrm{Mn}) / \mathrm{Ti}$ & 59 & 3535 & 25 & 22479 & 4236 & $(\mathrm{Fe}+\mathrm{Mn}) / \mathrm{Ti}$ & 14 & 4582 & 11 & 21443 & 6304 \\
\hline
\end{tabular}

Анализы выполнены атомно-эмиссионным (с индуктивно связанной плазмой) методом на спектрометре Agilent 7500 с (Agilent Technologies, США) в центре коллективного пользования ДВГИ ДВО РАН. 
Таблица 2. Средний химический состав фосфоритов Японского моря ( \%)

\begin{tabular}{|c|r|r|r|r|r|}
\hline $\begin{array}{c}\text { 4элемент } \\
\text { ы }\end{array}$ & $\begin{array}{r}\text { к-во } \\
\text { проб }\end{array}$ & $\begin{array}{c}\text { медиан } \\
\mathrm{a}\end{array}$ & $\begin{array}{c}\text { миниму } \\
\text { м }\end{array}$ & $\begin{array}{c}\text { максиму } \\
\text { м }\end{array}$ & $\begin{array}{r}\text { станд. } \\
\text { откл. }\end{array}$ \\
\hline $\mathrm{P}_{2} \mathrm{O}_{5}$ & 45 & 25.96 & 2.87 & 30.64 & 6.12 \\
\hline $\mathrm{SiO}_{2}$ & 36 & 11.31 & 1.22 & 47.30 & 12.19 \\
\hline $\mathrm{TiO}_{2}$ & 36 & 0.15 & 0.03 & 1.37 & 0.24 \\
\hline $\mathrm{Al}_{2} \mathrm{O}_{3}$ & 40 & 2.38 & 0.67 & 10.81 & 2.09 \\
\hline $\mathrm{Fe}_{2} \mathrm{O}_{5}$ & 40 & 2.81 & 1.20 & 9.80 & 1.56 \\
\hline $\mathrm{FeO}$ & 13 & 0.45 & 0.04 & 2.87 & 0.74 \\
\hline $\mathrm{MnO}$ & 26 & 0.15 & 0.02 & 1.22 & 0.27 \\
\hline $\mathrm{MgO}$ & 40 & 2.10 & 0.76 & 4.61 & 0.93 \\
\hline $\mathrm{CaO}$ & 36 & 40.16 & 11.95 & 46.97 & 9.24 \\
\hline $\mathrm{Na}_{2} \mathrm{O}$ & 25 & 1.24 & 0.50 & 2.86 & 0.65 \\
\hline $\mathrm{K}_{2} \mathrm{O}$ & 25 & 1.12 & 0.23 & 2.92 & 0.82 \\
\hline $\mathrm{CO}_{2}$ & 40 & 3.95 & 0.40 & 6.58 & 1.14 \\
\hline$П . п . П$. & 26 & 10.68 & 6.06 & 14.29 & 1.79 \\
\hline $\mathrm{F}$ & 30 & 2.15 & 0.30 & 3.34 & 0.70 \\
\hline
\end{tabular}

Данные химического состава фосфоритов взяты из работ

[Берсенев и др., 1983; Леликов, 2001]. 
Таблица 3. Химический состав баритовых конкреций Японского моря (BaO-п.п.п. в \%, Sr-As - г/т)

\begin{tabular}{|c|c|c|c|c|c|c|c|c|c|c|}
\hline & \multirow{3}{*}{$\begin{array}{c}\text { возв. } \\
\text { Ямато } \\
\text { Вал. } \\
\text { проба }\end{array}$} & \multicolumn{7}{|c|}{ хребет Окусири } & \multicolumn{2}{|c|}{$\begin{array}{l}\text { банка } \\
\text { Сингури }\end{array}$} \\
\hline & & \multicolumn{2}{|c|}{ Обр. 1} & \multicolumn{2}{|c|}{ Обр. 2} & \multicolumn{3}{|c|}{ Обр. 3} & \multirow[b]{2}{*}{ Обр.1 } & \multirow[b]{2}{*}{ Обр.2 } \\
\hline & & $\begin{array}{c}\text { Краевая } \\
\text { часть }\end{array}$ & $\begin{array}{c}\text { Центр. } \\
\text { часть }\end{array}$ & $\begin{array}{c}\text { Краевая } \\
\text { часть }\end{array}$ & $\begin{array}{c}\text { Вал. } \\
\text { проба }\end{array}$ & $\begin{array}{c}\text { Краевая } \\
\text { часть }\end{array}$ & $\begin{array}{c}\text { Черный } \\
\text { прожилок }\end{array}$ & $\begin{array}{c}\text { Вал. } \\
\text { проба }\end{array}$ & & \\
\hline $\mathrm{BaO}$ & 58.00 & 53.07 & 55.21 & 51.92 & 49.13 & 53.07 & 53.73 & 45.35 & 48.01 & 55.75 \\
\hline $\mathrm{SO}_{3}$ & 31.51 & 27.44 & 29.72 & 27.18 & 22.29 & 24.44 & 31.21 & 23.75 & 28.71 & 29.15 \\
\hline $\mathrm{SiO}_{2}$ & 0.36 & 10.00 & 5.50 & 7.31 & 14.90 & 10.19 & 0.24 & 15.34 & H.a. & H.a. \\
\hline $\mathrm{TiO}_{2}$ & 0.38 & 0.09 & 0.05 & 0.41 & 0.09 & 0.05 & 0.03 & 0.10 & H.a. & H.a. \\
\hline $\mathrm{Al}_{2} \mathrm{O}_{3}$ & 1.27 & 1.64 & 1.82 & 2.60 & 3.00 & 2.90 & 1.55 & 2.90 & H.a. & H.a. \\
\hline $\mathrm{Fe}_{2} \mathrm{O}_{3}$ & 1.57 & 0.64 & 0.67 & 1.20 & 1.47 & 1.12 & 4.10 & 2.39 & 0.60 & 1.17 \\
\hline $\mathrm{MnO}$ & 0.44 & 0.07 & 0.14 & 1.25 & 0.17 & 0.11 & 0.11 & 0.17 & 0.02 & 0.03 \\
\hline $\mathrm{MgO}$ & 1.99 & 1.05 & 1.05 & 1.15 & 1.47 & 0.84 & 0.73 & 1.47 & H.a. & H.a. \\
\hline $\mathrm{CaO}$ & 1.72 & 1.29 & 1.50 & 1.07 & 1.50 & 1.72 & 1.50 & 1.72 & 0.07 & 0.06 \\
\hline $\mathrm{Na}_{2} \mathrm{O}$ & 0.08 & 0.12 & 0.14 & 0.25 & 0.32 & 0.32 & 0.03 & 39 & н.а. & н.a. \\
\hline $\mathrm{K}_{2} \mathrm{O}$ & 0.35 & 0.25 & 0.25 & 0.39 & 0.25 & 0.50 & 0.05 & 0.50 & н.а. & н.a. \\
\hline $\mathrm{P}_{2} \mathrm{O}_{5}$ & 0.09 & 0.10 & 0.15 & 0.12 & 0.05 & 0.01 & 0.01 & 0.02 & H.a. & H.a. \\
\hline n.n.n. & 0.96 & 2.08 & 1.48 & 2.76 & 3.40 & 2.64 & 6.12 & 4.56 & H.a. & H.a. \\
\hline $\mathrm{Sr}$ & 10000 & 10000 & 10000 & 5000 & 10000 & 2000 & 2000 & 6000 & 4735 & 1183 \\
\hline $\mathrm{Pb}$ & 10 & 5 & 8 & 10 & 20 & 6 & 60 & 10 & 186 & 186 \\
\hline $\mathrm{Zn}$ & 30 & H. O. & 30 & 30 & 50 & H. O. & 60 & 50 & H.a. & H.a. \\
\hline $\mathrm{Cu}$ & 10 & 20 & 20 & 20 & 30 & 30 & 50 & 50 & H.a. & H.a. \\
\hline $\mathrm{Ag}$ & H. 0. & H. O. & H. O. & H. 0. & H. O. & 0,1 & 0,3 & 5 & н.а. & н.а. \\
\hline $\mathrm{Ni}$ & 10 & 3 & 5 & 5 & 30 & 30 & 30 & 30 & H.a. & н.a. \\
\hline Co & 3 & H. 0. & H. O. & H. 0. & 10 & H. O. & 20 & H. 0. & H.a. & H.a. \\
\hline Mo & 3 & H. O. & 10 & 5 & 10 & 3 & 20 & 10 & н.а. & H.a. \\
\hline As & H. O. & H. 0. & H. $\mathrm{O}$. & H. 0. & H. 0. & H. 0. & 1000 & H. 0. & H.a. & н.a. \\
\hline
\end{tabular}

Анализы баритовых конкреций возвышенности Северное Ямато и хребта Окусири выполнены в ТОИ ДВО РАН методом «мокрой химии», аналитик Якушева И.Н; определение микроэлементов спектральным анализом в ЦЛ ПГО Примгеология. Данные по химическому составу конкреций банки Сингури взяты из работы [Okada et al., 1971].

н.а. - не анализировалось, н.о. - не определено 


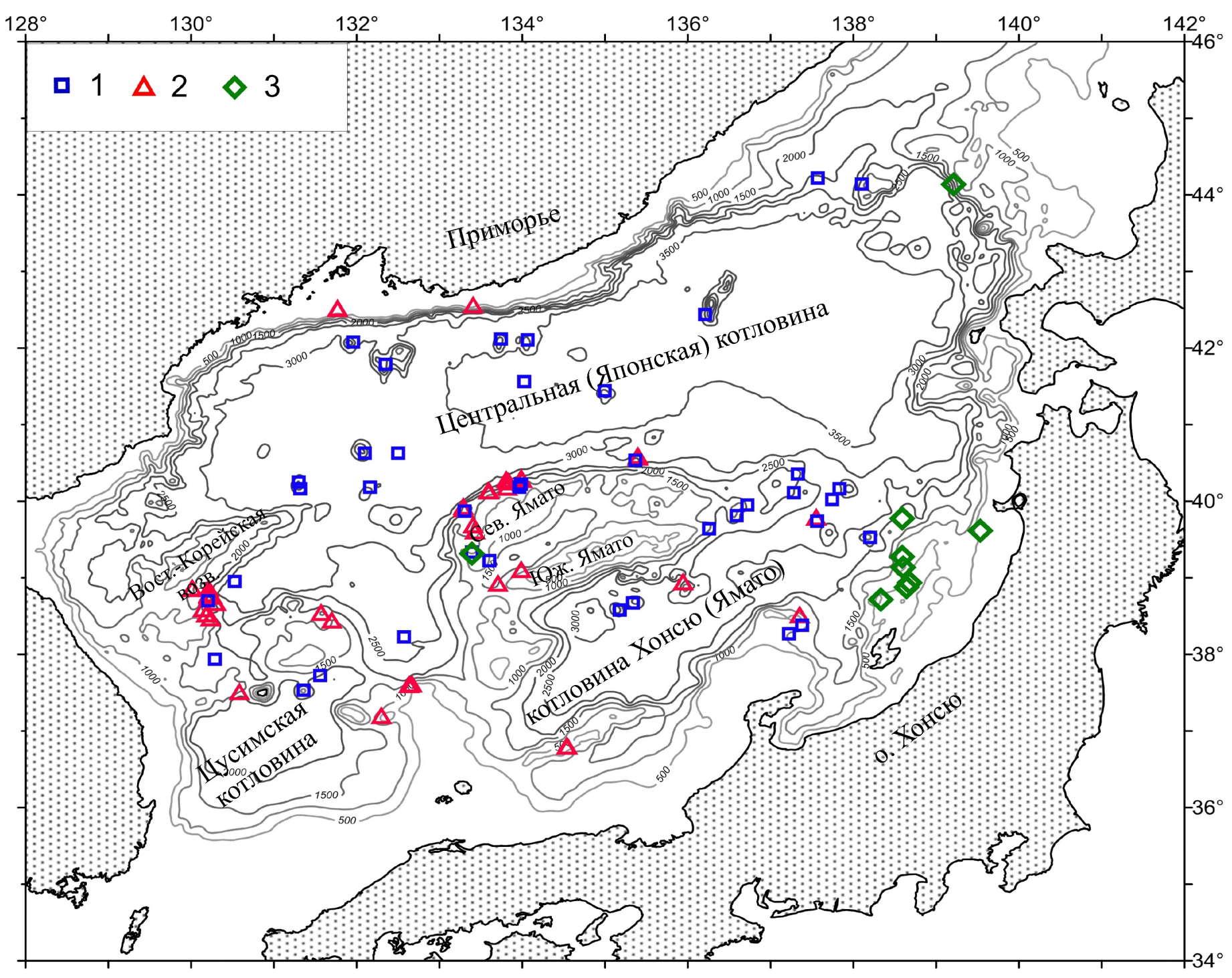




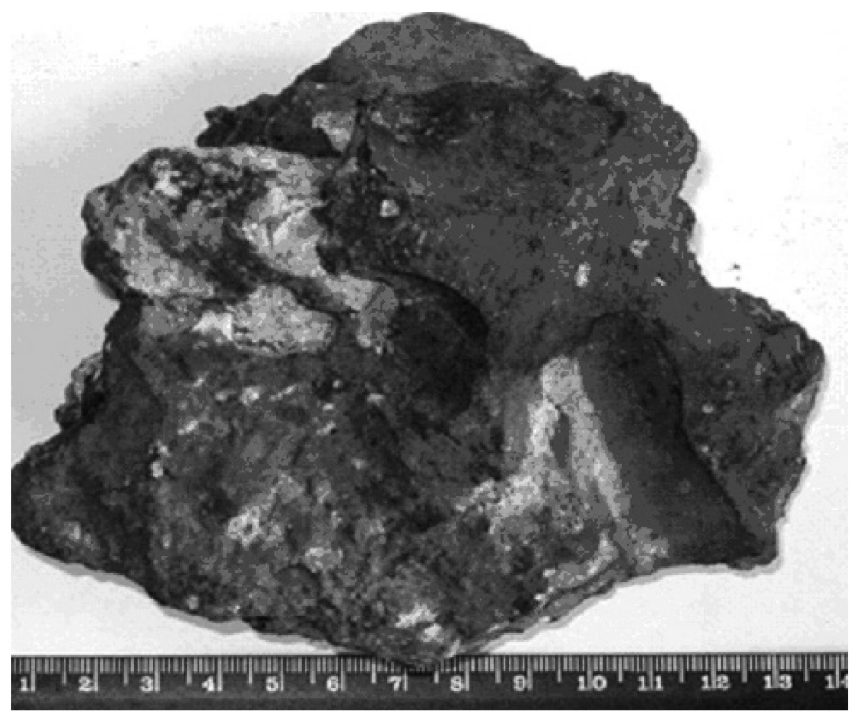

a

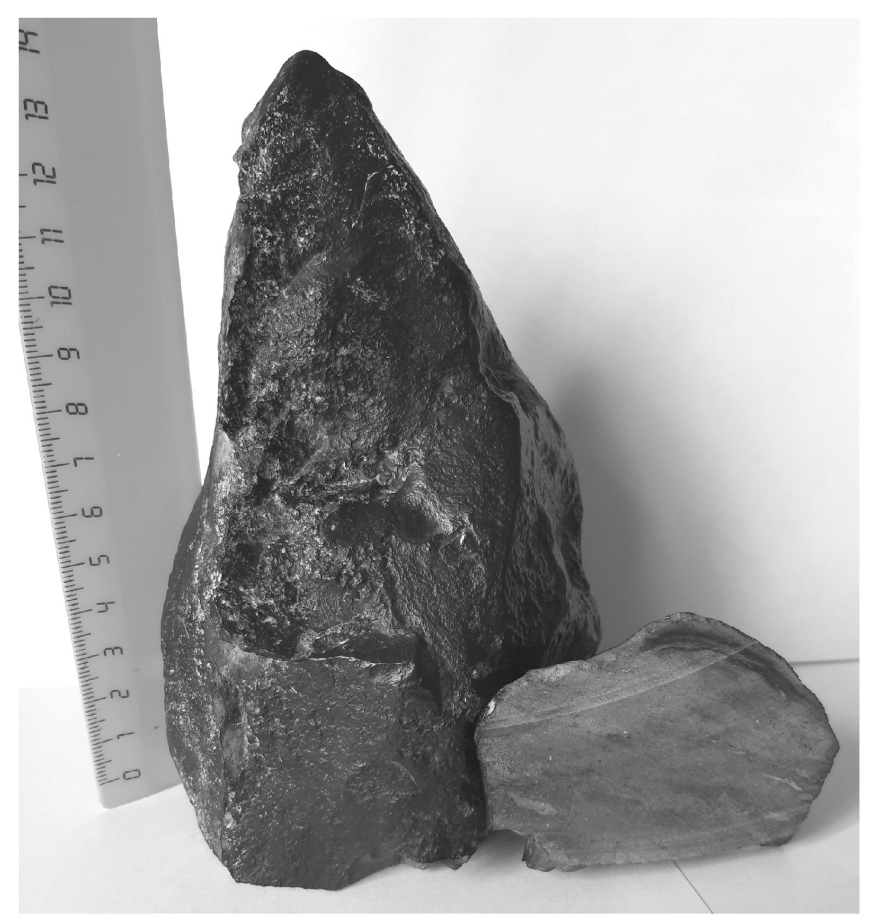

B

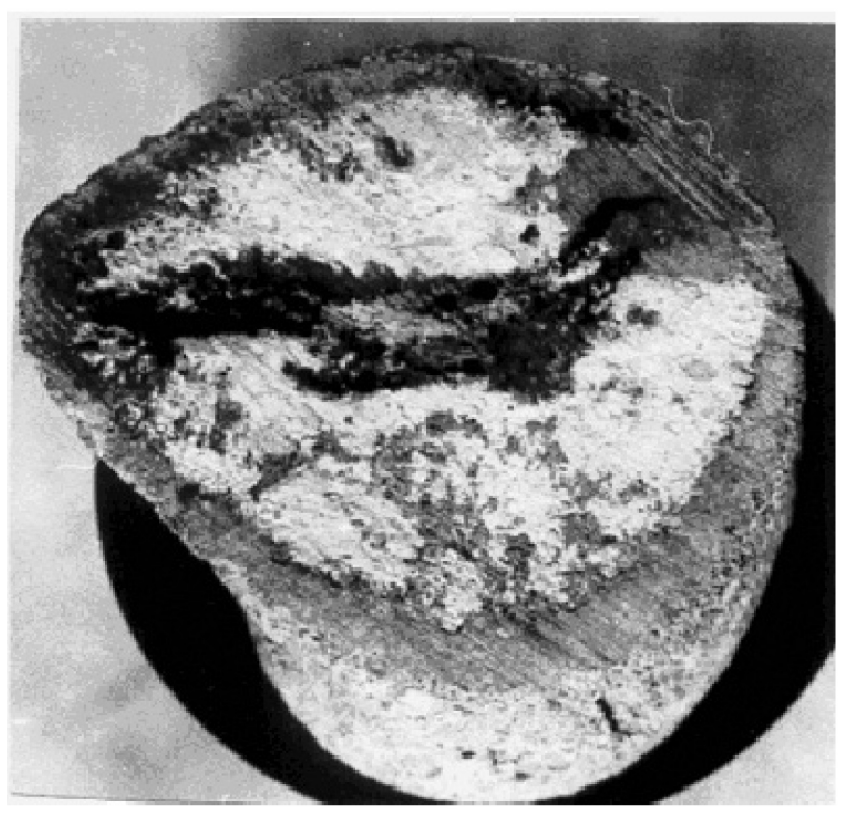

д

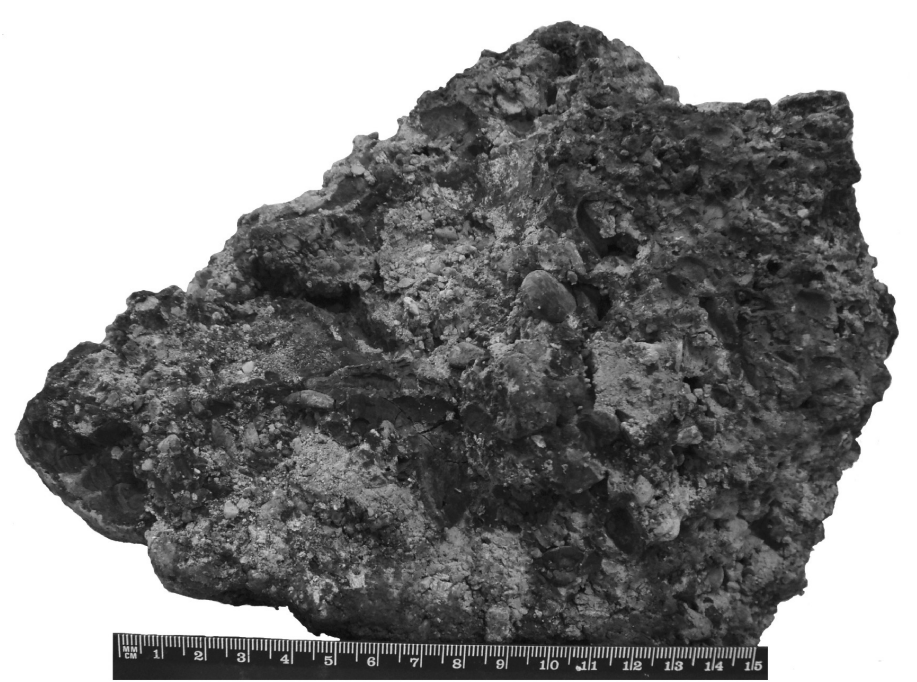

6

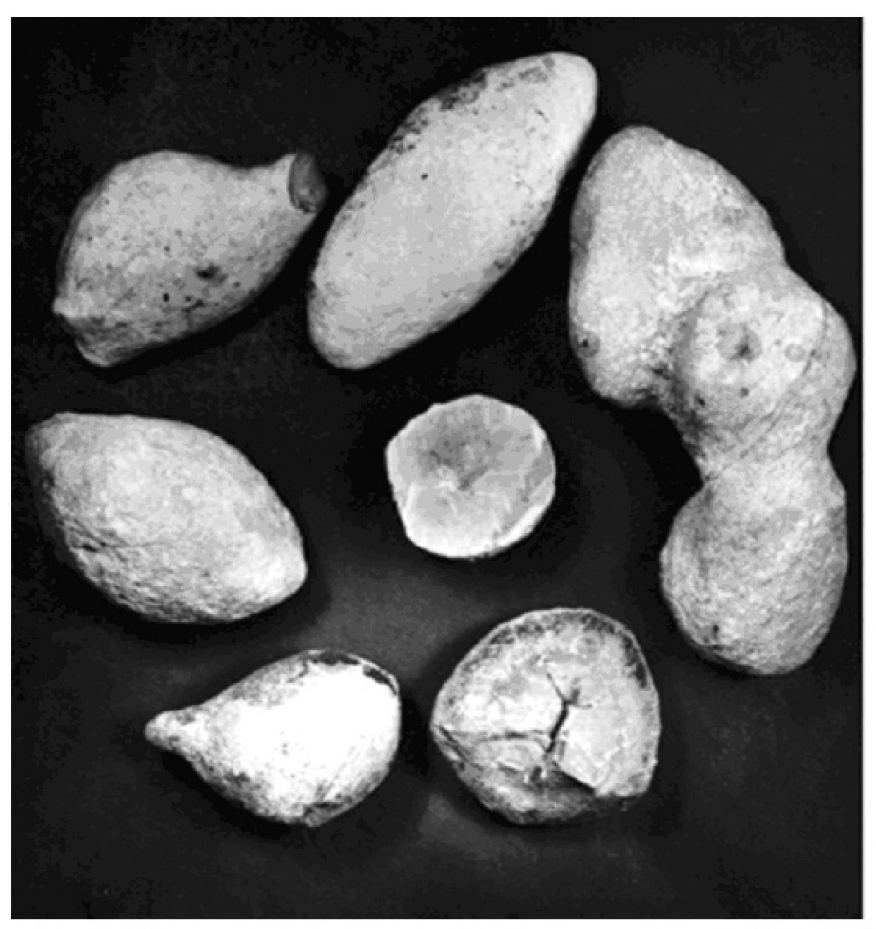

r
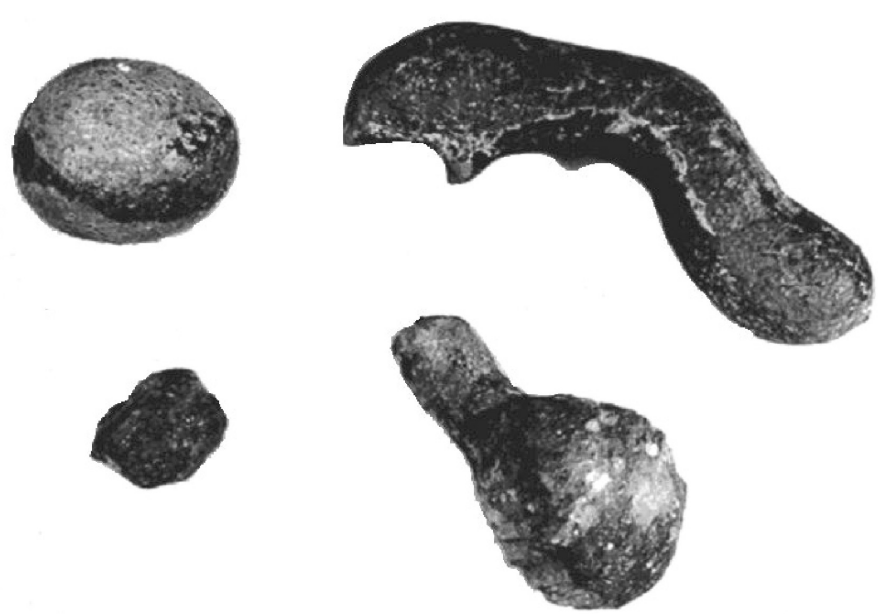

e 
Таблица 3. Химический состав баритовых конкреций Японского моря (BaO-п.п.п. в \%, Sr-As - г/т)

\begin{tabular}{|c|c|c|c|c|c|c|c|c|c|c|}
\hline & \multirow{3}{*}{$\begin{array}{c}\text { возв. } \\
\text { Ямато } \\
\text { Вал. } \\
\text { проба }\end{array}$} & \multicolumn{7}{|c|}{ хребет Окусири } & \multicolumn{2}{|c|}{$\begin{array}{l}\text { банка } \\
\text { Сингури }\end{array}$} \\
\hline & & \multicolumn{2}{|c|}{ Обр. 1} & \multicolumn{2}{|c|}{ Обр. 2} & \multicolumn{3}{|c|}{ Обр. 3} & \multirow[b]{2}{*}{ Обр.1 } & \multirow[b]{2}{*}{ Обр.2 } \\
\hline & & $\begin{array}{c}\text { Краевая } \\
\text { часть }\end{array}$ & $\begin{array}{c}\text { Центр. } \\
\text { часть }\end{array}$ & $\begin{array}{c}\text { Краевая } \\
\text { часть }\end{array}$ & $\begin{array}{c}\text { Вал. } \\
\text { проба }\end{array}$ & $\begin{array}{c}\text { Краевая } \\
\text { часть }\end{array}$ & $\begin{array}{c}\text { Черный } \\
\text { прожилок }\end{array}$ & $\begin{array}{c}\text { Вал. } \\
\text { проба }\end{array}$ & & \\
\hline $\mathrm{BaO}$ & 58.00 & 53.07 & 55.21 & 51.92 & 49.13 & 53.07 & 53.73 & 45.35 & 48.01 & 55.75 \\
\hline $\mathrm{SO}_{3}$ & 31.51 & 27.44 & 29.72 & 27.18 & 22.29 & 24.44 & 31.21 & 23.75 & 28.71 & 29.15 \\
\hline $\mathrm{SiO}_{2}$ & 0.36 & 10.00 & 5.50 & 7.31 & 14.90 & 10.19 & 0.24 & 15.34 & H.a. & H.a. \\
\hline $\mathrm{TiO}_{2}$ & 0.38 & 0.09 & 0.05 & 0.41 & 0.09 & 0.05 & 0.03 & 0.10 & H.a. & H.a. \\
\hline $\mathrm{Al}_{2} \mathrm{O}_{3}$ & 1.27 & 1.64 & 1.82 & 2.60 & 3.00 & 2.90 & 1.55 & 2.90 & H.a. & H.a. \\
\hline $\mathrm{Fe}_{2} \mathrm{O}_{3}$ & 1.57 & 0.64 & 0.67 & 1.20 & 1.47 & 1.12 & 4.10 & 2.39 & 0.60 & 1.17 \\
\hline $\mathrm{MnO}$ & 0.44 & 0.07 & 0.14 & 1.25 & 0.17 & 0.11 & 0.11 & 0.17 & 0.02 & 0.03 \\
\hline $\mathrm{MgO}$ & 1.99 & 1.05 & 1.05 & 1.15 & 1.47 & 0.84 & 0.73 & 1.47 & H.a. & H.a. \\
\hline $\mathrm{CaO}$ & 1.72 & 1.29 & 1.50 & 1.07 & 1.50 & 1.72 & 1.50 & 1.72 & 0.07 & 0.06 \\
\hline $\mathrm{Na}_{2} \mathrm{O}$ & 0.08 & 0.12 & 0.14 & 0.25 & 0.32 & 0.32 & 0.03 & 39 & н.а. & н.a. \\
\hline $\mathrm{K}_{2} \mathrm{O}$ & 0.35 & 0.25 & 0.25 & 0.39 & 0.25 & 0.50 & 0.05 & 0.50 & н.а. & н.a. \\
\hline $\mathrm{P}_{2} \mathrm{O}_{5}$ & 0.09 & 0.10 & 0.15 & 0.12 & 0.05 & 0.01 & 0.01 & 0.02 & H.a. & H.a. \\
\hline n.n.n. & 0.96 & 2.08 & 1.48 & 2.76 & 3.40 & 2.64 & 6.12 & 4.56 & H.a. & H.a. \\
\hline $\mathrm{Sr}$ & 10000 & 10000 & 10000 & 5000 & 10000 & 2000 & 2000 & 6000 & 4735 & 1183 \\
\hline $\mathrm{Pb}$ & 10 & 5 & 8 & 10 & 20 & 6 & 60 & 10 & 186 & 186 \\
\hline $\mathrm{Zn}$ & 30 & H. O. & 30 & 30 & 50 & H. O. & 60 & 50 & H.a. & H.a. \\
\hline $\mathrm{Cu}$ & 10 & 20 & 20 & 20 & 30 & 30 & 50 & 50 & H.a. & H.a. \\
\hline $\mathrm{Ag}$ & H. 0. & H. O. & H. O. & H. 0. & H. O. & 0,1 & 0,3 & 5 & н.а. & н.а. \\
\hline $\mathrm{Ni}$ & 10 & 3 & 5 & 5 & 30 & 30 & 30 & 30 & H.a. & н.a. \\
\hline Co & 3 & H. 0. & H. O. & H. 0. & 10 & H. O. & 20 & H. 0. & H.a. & H.a. \\
\hline Mo & 3 & H. O. & 10 & 5 & 10 & 3 & 20 & 10 & н.а. & H.a. \\
\hline As & H. O. & H. 0. & H. $\mathrm{O}$. & H. 0. & H. 0. & H. 0. & 1000 & H. 0. & H.a. & н.a. \\
\hline
\end{tabular}

Анализы баритовых конкреций возвышенности Северное Ямато и хребта Окусири выполнены в ТОИ ДВО РАН методом «мокрой химии», аналитик Якушева И.Н; определение микроэлементов спектральным анализом в ЦЛ ПГО Примгеология. Данные по химическому составу конкреций банки Сингури взяты из работы [Okada et al., 1971].

н.а. - не анализировалось, н.о. - не определено 